\title{
Una aportación a un diccionario histórico de lenguajes de especialidad: el léxico metafórico de tres tratados arquitectónicos del Renacimiento español (1526-1582)*
}

\author{
MARGARITA FREIXAS \\ Universidad Autónoma de Barcelona
}

\section{INTRODUCCIÓN}

El hermoso diálogo Las medidas del Romano de Diego de Sagredo (Toledo, Remon de Petras, 1526) es el primer tratado impreso que difunde en España algunos de los principios de la arquitectura renacentista. En concreto, describe en qué consiste la proporción en el diseño arquitectónico ornamental y cuáles son las características de las columnas según los distintos órdenes (dórico, jónico, corintio). La teoría expuesta procede de las ideas reunidas en las obras De architectura de Vitruvio (siglo I a. C.) y De re aedificatoria de Leon Battista Alberti (compuesta hacia 1450 y editada por primera vez en 1485). En la obra de Sagredo la difusión de la teoría arquitectónica supone la adopción de un léxico nuevo, que uno de los dos personajes del diálogo, Tampeso, trasunto del propio autor, explica a un amigo pintor, Picardo. Se trata de dar a conocer el vocabulario propio de la arquitectura, una profesión liberal:

architecto es vocablo griego; quiere dezir 'principal fabricador', e assí los ordenadores de edificios se dizen propriamente architectos, los quales, según parece por nuestro Vitruvio, son obligados a ser exercitados en las sciencias de Philosophía y artes liberales, ca de otra manera no pueden ser perfectos architetos, cuyas ferramientas son las manos de los oficiales mecánicos (Sagredo 1526: 14). ${ }^{1}$

* Esta contribución ha sido parcialmente financiada por el Grupo de Investigación Reconocido «Investigaciones lexicográficas y lexicológicas del español moderno y contemporáneo», dirigido por $\mathrm{M}^{\mathrm{a}}$ Jesús Mancho (Proyecto HUM2007-6070/FILO, financiado por la DGICYT), de la Universidad de Salamanca, y el «Grup de Lexicografia i diacronia» (SGR2009-1067), dirigido por Gloria Clavería, de la Universidad Autónoma de Barcelona.

${ }^{1}$ En el interior del artículo, las remisiones bibliográficas a los tratados arquitectónicos se hacen mediante el apellido del autor y el año de la primera edición de las obras. En la bibliografía final se indica la edición consultada, a la que pertenece el número de página de las citas, cuyo texto se encuentra reproducido en Mancho Duque y Quirós García (2005). 
La mayor parte de la terminología presente en Las medidas del Romano pertenece a la disciplina que el propio Sagredo denomina sciencia de architectura, que hay que distinguir del arte mecánica de la construcción ${ }^{2}$ (con el léxico específico de maestros y canteros). ${ }^{3}$

Los principios de la Arquitectura se difundieron en España a través de traducciones y comentarios manuscritos e impresos tanto de la obra de Vitruvio como de los humanistas que reinterpretaron el tratado clásico. ${ }^{4}$ Entre estos textos, ha sido poco estudiado el léxico de las únicas traducciones al español de las obras de Vitruvio y de Alberti que llegaron a imprimirse y que, por tanto, pudieron tener mayor difusión que las versiones manuscritas. Destacan, en especial, el tratado de Diego de Sagredo (1526), ya mencionado, el romanceamiento que realizó Miguel de Urrea (1582) del De architectura de Vitruvio y la traducción de Los diez libros de architectura de Leon Battista Alberti, atribuida a Francisco Lozano (1582). ${ }^{5}$ Las tres obras comparten la misma inquietud por difundir, en manuales impresos, el léxico de la arquitectura «al romano» o «a la antigua», según las denominaciones empleadas en la época para referirse al modelo clásico de edificación fijado en la Antigüedad grecorromana y recuperado en el Renacimiento. Para ello, sus autores recurren a la introducción de préstamos grecolatinos y a la incorporación de nuevos significados a palabras romances mediante procesos de analogía. ${ }^{6}$ En ambos casos, los términos suelen tener un origen metafórico, opaco en los extranjerismos y más transparente en algunas de las creaciones léxicas renacentistas. En este trabajo, mediante el estudio de la metáfora en los tratados de Diego de Sagredo, Miguel de Urrea y Francisco Lozano, se pretende realizar una primera aproximación al conocimiento de la presencia, los orígenes, la tipología y la pervivencia del léxico arquitectónico renacentista generado a través de mecanismos analógicos. ${ }^{7}$

${ }^{2}$ Aunque, como señalan Marías y Bustamante (1986: 10), Sagredo no menosprecia a los maestros de cantería, encargados de materializar las propuestas ornamentales de su tratado. Recuérdese que el propio Sagredo no fue un arquitecto y que, en el área de la construcción, no pasó de diseñar obras ornamentales efímeras para celebraciones religiosas (Marías 2000: 36).

${ }^{3}$ A pesar de que la obra de Sagredo se refiere exclusivamente a la decoración de los edificios y no a su estructura (por ello ha recibido el nombre de «tratado pre-arquitectónico», Marías y Bustamante 1986: 8) y, por lo tanto, entre su público más numeroso debieron figurar los oficiales y maestros canteros (Marías 2000: 11-13), el tratado no emplea los términos jergales propios de este oficio ( $c f$. Herráez Cubino 2006 y 2007a sobre este lenguaje), sino que trata de difundir las voces propias de la arquitectura clásica y renacentista.

${ }^{4}$ Bustamante, Marías, del Olmo y Sánchez Esteban (1986) y Criado Mainar (2004) dan cuenta de los principales tratados arquitectónicos del Renacimiento español.

${ }^{5}$ La traducción es anterior a 1578, año de la aprobación del volumen para su publicación en 1582, en Madrid, en casa de Alonso Gómez. Se ha dudado de la autoría de la obra. En la portada no aparece el nombre de Francisco Lozano, que se presenta como traductor en la dedicatoria a Juan Fernández de Espinosa, a pesar de que, en la licencia de impresión, se afirma que el propio Lozano informó al rey de que había «hecho traduzir» el tratado de Alberti (véase Lozano 1582: III y Bustamante y Marías 1986: 202). Morales ha atribuido la traducción a un cosmógrafo, Rodrigo Zamorano, del que se conserva una versión manuscrita de un fragmento del De pictura de Alberti y una nota autógrafa en la que se atribuye la autoría de una traducción de «Los diez libros dela architectura que debaxo de nombre ageno andan impresos, aunque no limados por havérseme tomado en borrador» (vid. Morales 1994: $455 \mathrm{y}$ Morales 1995: 142).

${ }^{6}$ Para la importancia del préstamo y la creación de palabras a través de la analogía en los textos científicos renacentistas, véase Gutiérrez Rodilla (1998: 59-73, esp. p. 69).

${ }^{7}$ Con esta finalidad se han examinado los tratados de Sagredo (1526), Urrea (1582) y Lozano (1582) para extraer de ellos las voces de origen metafórico. Se ha seleccionado un total de 76 palabras, que previamente a la redacción del presente trabajo se han analizado en fichas lexicográficas, siguiendo el modelo diseñado por Grupo de Investigación Reconocido «Investigaciones lexicográficas y lexicológicas del español moderno y contemporáneo», dir. M. ${ }^{a}$ Jesús Mancho, para la elaboración de un Diccionario de la Técnica y la Ciencia del Renacimiento. 


\section{LA METÁFORA EN EL LÉXICO ARQUITECTÓNICO GRECOLATINO Y SU PRESENCIA EN LA} TRATADÍSTICA DEL RENACIMIENTO ESPAÑOL

Tras los estudios de Le Guern (1973) y Lakoff y Johnson (1980), numerosos trabajos han demostrado la importancia de la metáfora como proceso central del pensamiento humano en general y, en particular, en el de carácter científico. ${ }^{8}$ Las analogías «sirven admirablemente a la economía del discurso científico» (Gutiérrez Rodilla, 1998: 150), pues a través de las relaciones que se establecen entre distintas realidades se facilita la comprensión de nuevas realidades y razonamientos. ${ }^{9}$ En el caso de la Arquitectura, como veremos, las metáforas se emplean para relacionar formas y funciones de la naturaleza, y particularmente las propias de las distintas partes del cuerpo humano, con elementos arquitectónicos..$^{10}$ De este modo, se consigue facilitar la comprensión de las características morfológicas y funcionales de los distintos componentes de una construcción, a la vez que se proyecta la idea de que la ciencia de la edificación se basa en la mímesis de la naturaleza.

Callebat (1995) ha demostrado la importancia de la metáfora en el léxico grecolatino, principal fuente de los tratados renacentistas dedicados a la construcción, ${ }^{11} \mathrm{y}$ ha analizado su presencia en el único manual de arquitectura de la Antigüedad clásica que conocemos, el $D e$ aquitectura de Vitruvio (Callebat y Fleury 1995). En sus trabajos destaca el hecho de que la mayoría de términos metafóricos, por lo común préstamos del griego, suelen establecer relaciones visuales entre un concepto arquitectónico y una forma conocida, ya sea una parte del cuerpo humano (ancon, calx, corpus, femur, frons, humerus, mentum, supercilium, oculus), un elemento vegetal (caliculus, flos, folium, helix) o una forma geométrica (unda). Estas voces, a su vez, son capaces de generar nuevas relaciones metafóricas. Así ocurre, por ejemplo, en el ámbito de lo antropomórfico, con la creación de términos arquitectónicos que evocan enfermedades humanas (parotis) y objetos relacionados con el hombre, como el vestido (uestidura, balteus) o el equipamento militar (lorica) (Callebat 1995: 635-636). Este léxico grecolatino de origen metafórico se incorpora a la tratadística renacentista dedicada a la Arquitectura, como lo demuestra la presencia de estos términos en la obra de Diego de Sagredo (1526). En este

${ }^{8}$ Entre la abundante bibliografía publicada acerca de la importancia de los procesos metafóricos en el pensamiento humano y su presencia en el léxico, pueden verse Llamas (2005), donde se encuentra un repaso histórico del tratamiento de este fenómeno en la semántica tradicional y en la semántica cognoscitiva, y Deignan (2005), que, a la síntesis de los modelos teóricos existentes para el estudio de la metáfora, añade la propuesta de una metodología de análisis a través de su presencia en corpus de textos actuales. Véase también una descripción de los principales mecanismos de neología fruto de cambios semánticos, entre ellos, la metáfora, en Santos Domínguez-Espinosa Elorza (1996: 23-48).

${ }^{9}$ Martín Municio (1992) y Chamizo Domínguez (1998) advierten que, en un principio, los neologismos generados por procedimientos metafóricos tienen su origen en analogías creativas con una clara función cognoscitiva: ayudan a comprender mejor el concepto que expresan y, además, generan una serie de redes léxicas en las que se relacionan términos que comparten un mismo símil.

${ }^{10}$ Pueden encontrarse más ejemplos de analogías en el lenguaje científico en Gutiérrez Rodilla (1998: 147149), así como referencias bibliográficas en que se analiza la metáfora como un «proceso casi intrínseco al pensamiento científico» (Gutiérrez Rodilla 1998: 150). La importancia del cuerpo humano para el desarrollo del pensamiento y del lenguaje ha sido puesta de relieve, entre otros, por Johnson (1984).

${ }^{11}$ La metáfora es también un procedimiento fundamental en la creación de otros lenguajes de especialidad, como ocurre en la terminología médica de origen griego. Véase al respecto Maquieira (1998). En cuanto a la lengua en el Renacimiento, Mancho Duque (2005) ha estudiado las metáforas corporales en el lenguaje científico-técnico, y Cantillo (2005) la presencia de la metáfora en el léxico de la destilación. 
diálogo humanista se introducen numerosos préstamos grecolatinos acompañados de una definición sucinta en la que a menudo se recuerda el origen metafórico de los términos. La explicación de la etimología de la palabra suele recuperar relaciones metáforicas perdidas que el lector ya es incapaz de reconocer, en algunos casos por desconocimiento del significado de la palabra en su lengua de origen (véase, abajo, el caso de trochilo) y en otros porque el término ha sufrido un proceso de lexicalización o catacresis (véase, abajo, talón). ${ }^{12}$ De este modo, Sagredo evoca la existencia de una motivación del significante basada en la mímesis de una imagen o forma, como ocurre en los comentarios acerca de trochilo y talón:

Trochilo es otro miembro principal en la basa que, por semejar al carrillo o polea, le llamaron los griegos trochilo, que quiere dezir 'rodaja' (Sagredo 1526: 37).

Talón es otra moldura que se llama assí porque semeja al calcaño o tovillo del hombre, que en latín se dize tallus, e tiene la misma buelta que la gula, salvo que la tiene al revés (Sagredo 1526: 19).

Habitualmente, acompaña sus afirmaciones con grabados que sirven para identificar los términos y las relaciones metafóricas aprendidas. Así, por ejemplo, la imagen de un rostro ayuda a recordar las distintas molduras, entre las que se encuentra el talón:

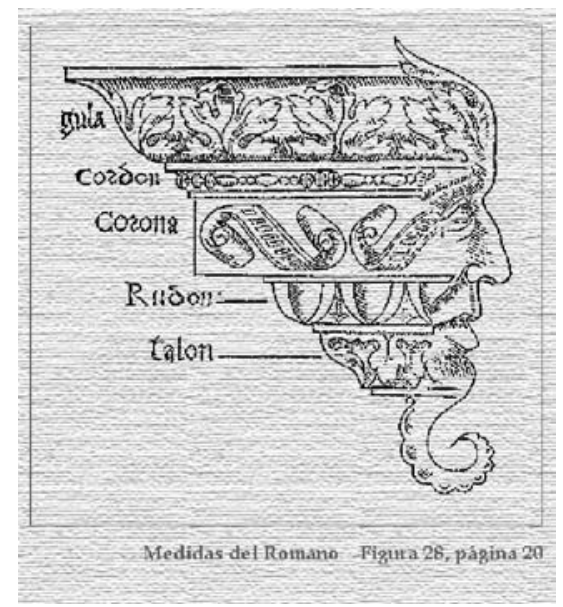

Fig. 1. Imagen de las Medidas del Romano, Sagredo (1526: 20), reproducida en Mancho Duque y García Quirós (2005)

Las relaciones metafóricas recuperadas por Diego de Sagredo no se limitan a las formas, geométricas o humanas, que evocan los términos arquitectónicos, sino que también se toman como puntos de referencia otras propiedades de la naturaleza, como la oscuridad:

${ }^{12}$ Villar Díaz (2001) define la catacresis como un proceso de traslación del significado que puede tener su origen en la metáfora o la metonimia, pero que se caracteriza por la lexicalización de los términos obtenidos por catacresis y por el mayor grado de concreción semántica que éstos presentan respecto a las expresiones metafóricas y metonímicas menos convencionales. 
Escota es otra moldura cavada y metida hazia dentro. Y porque su buelta se retira y no recibe luz, la llamaron los griegos scotia, que quiere dezir 'obscuro'. Algunos quieren fingir que es la corteza del bozel. Esta moldura es por los modernos llamada media caña (Sagredo 1526: 18).

El mismo procedimiento de recuperación de metáforas muertas a través de explicaciones etimológicas se encuentra en la traducción de Miguel de Urrea. La productividad de este proceso queda especialmente de manifiesto en el error que éste comete al identificar, de forma equivocada, el origen de toro, pues la falsa etimología, taurus, por torus, le conduce a una analogía desviada y, con ella, a una interpretación incorrecta del término:

toro, dízese a imitación de los animales patihendidos y también se dize escocia y labio superior y inferior (Urrea 1582: III, III, 42v, en la aclaración que acompaña a la figura). ${ }^{13}$

En los ejemplos señalados se observa una característica propia de la terminología arquitectónica renacentista: la convivencia de términos sinonímicos para designar un mismo elemento. Es frecuente que los préstamos, escota y toro en este caso, compartan una misma designación con otras voces, que, a su vez, expresan nuevas relaciones metafóricas, como ocurre con media caña o labio superior e inferior. La serie de voces que designan este tipo de moldura se completa con las consideraciones de Sagredo sobre murecillo, otro término latino de origen metafórico (pues en su sentido literal equivale a 'músculo', a su vez voz derivada del diminutivo de mus, 'ratón'), sinónimo de toro, escota o escocia, media caña, labio superior y labio inferior:

Murezillo se llama el bozel redondo que se halla en la basa, al qual los antiguos llamavan torus, que quiere dezir 'cierta carne dura y nervosa donde consiste la fuerça'. La figura d'este miembro, quando se pone por sí, es como una hogaza de pan (Sagredo 1526: 37).

En los textos de Diego de Sagredo y de Miguel de Urrea, las consideraciones sobre la etimología de las voces, así como la explicación de las metáforas de vocablos de origen grecolatino, constituyen un método didáctico para difundir y glosar un conjunto de términos nuevos en español. Éste es precisamente uno de los objetivos del tratado de Sagredo y de las traducciones de Urrea y de Lozano, pues todos ellos comparten en los prólogos de sus obras una misma idea: tienen plena conciencia de que están contribuyendo a enriquecer la lengua con una nueva terminología, ${ }^{14}$ propósito que, como ha demostrado Mancho Duque (2001), se declara explícitamente en los prólogos de la mayor parte de tratados científicos y técnicos del Renacimiento español. ${ }^{15}$

\footnotetext{
${ }^{13}$ Miguel de Urrea (1582) emplea el mismo símil para referirse al talo, al parecer sinónimo de la moldura llamada troquilo: «una parte [del toro alto de un plinto] con sus astrágalos y sobrecejo será el superior trochilo, que es dezir el talo, como en los animales patihendidos lo asurcado y el trochilo baxero» (III, III, 41 ${ }^{\mathrm{v}}$ ).

${ }^{14}$ Precisamente la conciencia de este hecho provoca que Urrea considere necesario incluir al final de su traducción un «Vocabulario de los nombres obscuros y difficultosos que en Vitruvio se contienen», estudiado por Herráez Cubino (2007b). En este repertorio léxico se ofrecen breves definiciones de tecnicismos grecolatinos de difícil comprensión incluidos en el tratado.

${ }^{15}$ Un estudio de las características lingüísticas de los tratados científico-técnicos en el Renacimiento se encuentra en Mancho Duque (2003 y 2004).
} 
Sin embargo, ninguna de las tres obras estudiadas es fruto de una labor filológica y humanística de alto calado. En muchos pasajes, Urrea y en especial Lozano no profundizaron en la exégesis de sus fuentes, pues a menudo se limitaron a adoptar los términos del original sin recurrir al empleo de voces equivalentes en español. Un ejemplo de un procedimiento de carácter más humanista se encuentra en la traducción de Lázaro de Velasco del De architectura de Vitruvio (1555), manuscrito que nunca llegó a publicarse. En éste se encuentran comentarios especialmente interesantes, pues es notable su preocupación por comprender las voces grecolatinas y por emplear términos castellanos equivalentes. ${ }^{16}$ Estas correspondencias contribuyen a ilustrar la existencia de un léxico de arquitectura metafórico castellano que no siempre dependía de las voces latinas. Para alato, por ejemplo, ofrece los sinónimos castellanos que aluden a la idea de 'sucesión' o 'baile' de elementos arquitectónicos, 'bóvedas', 'arcos' o 'naves':

Lo que dize Vitruvio alato y nosotros hilera de bobedado o dança de arcos con caxcos llaman los toscos officiales nabada, que es 'hilera de nabe' (Velasco 1999 [1555]: 133).

Como contraste, los textos de Sagredo, Urrea y Lozano son sobre todo testimonios valiosos para el estudio de la entrada en el léxico arquitectónico de voces metafóricas prestadas del griego y del latín, y apenas ofrecen muestras de creaciones en español, que deberán rastrearse en futuros trabajos dedicados a analizar una documentación no tan cercana a la traducción ad litteram de los manuales clásicos y renacentistas.

\section{LA METÁFORA EN EL LÉXICO ARQUITECTÓNICO HUMANISTA Y SU PRESENCIA EN LA TRATADÍSTICA} DEL RENACIMIENTO ESPAÑOL

En los primeros tratados arquitectónicos del Renacimiento español no sólo es posible constatar la adopción y la recuperación de voces de la Antigüedad clásica, sino también la presencia de un vocabulario nuevo, procedente de obras científicas humanistas. En este sentido, el desarrollo del léxico arquitectónico en los siglos XV y XVI queda reflejado especialmente en el De re aedificatoria (compuesto c. 1450 e impreso por primera vez en 1485), de Leon Battista Alberti, y su traducción, Los diez libros de Architectura de León Baptista Alberto (1582), de Francisco Lozano. En este texto no sólo se emplea el léxico metafórico clásico, sino que se potencia la metáfora como un recurso retórico que tiene el fin de hacer más atractiva y comprensible una nueva ciencia: la Arquitectura. Hay que tener presente que, durante toda la Edad Media, los métodos de construcción eran saberes prácticos que, de manera muy secreta, difundían los alarifes entre sus aprendices. La concepción de la Arquitectura como un arte liberal, para la que se necesitan conocimientos teóricos y prácticos, y el deseo de difundir esta ciencia conducen a la elaboración de manuales, como el de Alberti, con unas marcadas técnicas pedagógicas. ${ }^{17}$

${ }^{16}$ Para un análisis de la traducción de Lázaro de Velasco, véase Pizarro-Mogollón (1999: 41-47), con datos relevantes, como la comparación entre la versión de Miguel de Urrea, con numerosas voces griegas y latinas, y el texto de Velasco, que incluso llega a suprimir un fragmento porque «todo lo demás deste capítulo en el libro del latín ni italiano es de provecho para los maestros ni officiales[,] que no es sino una declaración de nombres griegos» (fol. 100v, cit. en Pizarro-Mogollón 1999: 42).

${ }^{17}$ Para una visión acerca de las prácticas arquitectónicas de la Edad Media y de los Siglos de Oro, véase Cámara (1990) y García Morales (1991). 
En un fragmento del tratado de Alberti, que ofrecemos en la traducción de Lozano, el autor declara precisamente la necesidad de hacer comprensible su mensaje sirviéndose, cuando sea necesario, de la creación de nuevas palabras mediante el recurso a la metáfora: ${ }^{18}$

He prometido, y querríalo yo quanto en mí fuesse, hablar latinamente y de suerte que sea entendido; por tanto, conviene fingir vocablos quando los que se usan no sirven, y aprovecha tomar las semejanças de los nombres de cosas no dessemejantes. Collarino llaman acerca de nós, los de Toscana, una cinta muy delgada, con que las donzellas atan y ciñen los cabellos; llamemos, pues, collarino (si nos es lícito) la faxuela que como regla flechada en redondo rodea en lugar de anillo la estremidad de la columna. Pero el anillo en lo alto, fuera del collarino, que rebuelto como soga aprieta la más alta redondez de la columna, llamémosle mazzocho (Lozano 1582: VI, XIII, 187188).

El proceso de romanceamiento de este pasaje resulta sumamente interesante para el estudio de la traducción de los tecnicismos. En este fragmento Leon Battista Alberti empleó las voces nextrum y torquem (1486: VI, XIII, 525), que Cossimo Bartoli (1550), en la versión italiana de la obra, sustituye por collarino y mazzochio, respectivamente, ${ }^{19}$ voces que adopta Francisco Lozano, quien debió de consultar tanto el texto original latino como la traducción de Bartoli. ${ }^{20}$ Es probable que a Lozano le pareciera aceptable que un lector español pudiera relacionar el término collarino con un adorno para las mujeres, de manera que la relación metafórica aseguraba la comprensión de las características del elemento arquitectónico al que hacía referencia. Collarino es un italianismo que tuvo fortuna en el léxico arquitectónico, pues en el siglo XVI lo emplean Juan de Arfe y Villafañe (Varia conmensuración para la escultura y arquitectura, 1585-1587) y Patricio Caxesi Florentino (en la traducción de la Regla de las cinco órdenes de architectura, de Jacome de Vignola, 1593), y en los siglos XVII y XVIII, Juan de Villaviciosa (La Moschea, 1615) y Antonio Palomino de Castro y Velasco (Museo pictórico y escala óptica, 1715-1724), ambos citados en el Diccionario de Autoridades (s. v.), que define el término de forma analógica:

COLLARINO. s. m. Voz de la Architectúra. El anillo que termína la parte superior de la colúna, y recibe el capitél. Llamóse assi por ser circulár, y à manera de anillo.

${ }^{18}$ La retórica de Alberti, plagada de símiles con una voluntad pedagógica, viene justificada también por el tipo de público al que se dirigía la obra; según Grafton (2000: 377), no se destinaba «tanto a coloro che construivano per professione, quanto ai signori, agli ecclesiastici e agli intellettuali che speravano di dirigere il loro lavoro».

${ }^{19}$ A pesar de que Bartoli (1550) omite este párrafo, en el anterior traduce nextrum por collarino y torquem por mazzochio. Cf. Alberti (1486: XIII, VI, 525): «praeter nextrum et inflexam hanc obliquitatem habet etiam torquem» y Bartoli (1550: 196): «ha oltre al collarino \& alla piegatura, ancora il mazocchio».

${ }^{20}$ Francisco Lozano (1582) conocía la traducción de Bartoli, pues la menciona en el Prólogo: «Pero uno de los que mejor escrivieron, a mi parecer, después de Vitrubio, fue León Baptista Alberto, florentín, el qual en lengua latina compuso diez libros d'esta sciencia. Cosme Bartoli los traduxo en lengua toscana, en beneficio de su patria, y en ella los sacó a luz» (pp. V-VI). La presencia de numerosos italianismos, como grosseza, caveto, mazzocho, collarino..., demuestran que Lozano contó con la traducción italiana, además del original latino, del que también toma numerosas voces, como pitiutosos (p. 10), proluvie (p. 12) y sagita (sagitta, p. 55). 
En cambio, la voz italiana mazzochio, que, en español, no permitía establecer símiles de ningún tipo, sólo fue adoptada por Lozano, con las variantes mazocho, mazoco y mazzocho. ${ }^{21}$

En otros lugares de su obra, además del pasaje mencionado, Alberti reflexiona sobre la necesidad de recurrir a las metáforas en el discurso arquitectónico. De especial interés es un fragmento en el que reconoce que el lenguaje propio de los arquitectos emplea las metáforas como forma de expresión. Al referirse a un término de la geometría, la sección del círculo, afirma que «acerca de nós, los architectos, por causa de semejança, se llama aquí arco» (Lozano 1582: 18). ${ }^{22}$ Lozano comprende y emula el recurso a la creación de nuevas palabras mediante el empleo de símiles e introduce en su traducción numerosos términos metafóricos sin tratar de sustituirlos por otros tecnicismos. Sin embargo, la mayoría de innovaciones léxicas de Alberti, fruto de metáforas voluntarias no convencionales, no tendrán fortuna en España más allá de la traducción de Lozano, pues la lengua no las acogerá como términos de especialidad debido a que se trata de designaciones poco precisas que no permiten identificar adecuadamente los distintos elementos de la construcción.

Esto ocurre, por ejemplo, con los términos que relacionan la estructura de un edificio con un árbol, pues sus paredes tienen raíces, los fundamentos (Lozano 1582: 345-346), o bien con la osamenta y el sistema nervioso de un animal. Los pilares, columnas y arcos reciben el nombre de huesos $^{23}$ y esta metáfora creativa genera numerosos símiles para designar piezas arquitectónicas. ${ }^{24}$ Se parte de la observación de la naturaleza y de su emulación surge una concepción arquitectónica de carácter anatómico. Así, como los animales, los edificios tienen sus huesos unidos con nervios y ataduras: ${ }^{25}$

Advirtieron los philósophos en los cuerpos de los animales aver acostumbrado la naturaleza perfectionar de tal suerte su obra, que no aya querido que en algún tiempo estuviessen los huessos a los huessos, y los affirmaremos muy bien con nervios y ataduras, para que sea la orden y com-

${ }^{21}$ Entre los repertorios lexicográficos, Clairac (1877-1891: s. v. mazocho) incluye la voz con un pasaje de la traducción de Lozano: «(Arq.) ant. ||*Anillo más alto del capitel. [...] ||*Voz italiana que alguna vez se ha empleado en lugar de toro. "Los mazochos son unos ciertos rolletes gruessos en la basa, con el uno de los quales se aprieta la coluna, y el otro está assentado en el dado" (Leon B. Alberti -Traducción de Lozano. Lib. VII.-Cap. VII)». Vera afirma que el término «deriva de la palabra italiana mazzochio con la que se indicaba a los adornos en cuadros blancos y negros, colocados sobre una superficie toral [...]. El término fue utilizado en la traducción que F. Lozano hizo de Alberti, y designa a la moldura semicircular» (2004: s. v. mazocho).

${ }^{22}$ Cf. Alberti (1486: 55): «apud nos hic architectos similitudinis gratia arcus vocatur».

${ }^{23}$ «Ay también entre las principales partes de la pared, aun en las principales, ángulos y pilares o columnas enxeridas y entrepuestas, o otra cosa assí, la qual está en lugar de columnas para sostener los envigamientos y los arcos de los techos, las quales cosas todas vienen con nombramiento de huessos [...]. Demás de esto, el techo de las aberturas, que es lo de sobre la entrada, ahora esté puesto con viga derecha o con arco tirado, será contado entre los mismos huessos, porque el ser arco no diré yo que es otra cosa que una viga flechada» (Lozano 1582: 71).

${ }^{24}$ Incluso la observación de que en todos los animales el número de huesos es par y de que sólo tienen una boca determina el número de los elementos que sustentan el edificio y el número de entradas: «los huessos del edificio siguiendo a la natura, esto es: las columnas, esquinas y cosas tales, nunca los pusieron en número impar, porque ningún animal daréys que esté o se mueva sobre pies impares y también, por el contrario, en ninguna parte pusieron aberturas en número par. Lo qual es claro aver guardado la natura, pues puso a los animales de una y otra parte orejas, ojos, narizes, aunque pares, pero en el lugar de en medio puso la boca una y grande» (Lozano 1582: 282).

${ }^{25}$ De todos los elementos que recuerdan la estructura ósea y nerviosa de un animal, sólo nervio se ha lexicalizado como tecnicismo. A pesar de la presencia del término ya en los tratados arquitectónicos renacentistas, no se incluye en el Diccionario académico hasta su duodécima edición: 'Arco saliente en el intradós de una bóveda' (DRAE1884, s. v. nervio). 
postura de los huesos tal, que con ella sola, aunque falten las demás cosas, esté en pie la obra y perfectionada con sus miembros y firmezas (Lozano 1582: III, 84).

A lo largo del texto aparecen otros sinónimos de nervios y ataduras. En la construcción de las bóvedas, se propone unir los huesos con ligaduras ('arcos de crucería'; Lozano 1582: 87) y se recuerda que en su construcción deben imitarse las junturas de la naturaleza, los vellecillos y ataduras:

La bóveda, comoquiera que ella sea, imitaremos la naturaleza; la qual, quando ajuntó huessos, entremetió las mismas carnes con vellecillos y ataduras enxeridos por todos los diámetros en largo, en ancho, en alto, en bajo y al través (Lozano 1582: 88-89).

Siguiendo con la proyección de la imagen del animal, la bóveda es la espalda ${ }^{26}$ y las dovelas centrales de cada arco son los ñudos del espinazo, ${ }^{27}$ e incluso la clave ${ }^{28}$ se identifica con el espinazo. ${ }^{29}$ Las dovelas, cuños en la traducción de Lozano, sirven también para conformar los costados de la bóveda, que cuenta incluso con riñones, las renes (Lozano 1582: 86 y 263), latinismo que designa a ciertas piedras que sustentan la parte interior de un arco. Y, en las columnas, la parte central es el meollo (Lozano 1582: 187), analogía que también empleó Diego de Sagredo al referirse al tuétano de las columnas (1526: 26).

Leon Battista Alberti, y con él su traductor, Francisco Lozano, fueron originales en la creación de estos símiles, aunque también aprovecharon términos metafóricos procedentes del texto de Vitruvio. Es lo que ocurre cuando, al tratar de las chimeneas, se refieren a su nariz, voz que, como recogen Callebat y Fleury, ya se empleó en la Antigüedad para referirse a las salidas de aire en hornos, muros y máquinas (1995: 58, 125, 256). A partir de esta analogía antropomórfica, se potencia la comparación con la alusión a la garganta, a la boca de la garganta y a la cabeza de la chimenea (Lozano 1582: V, XVII, 154). ${ }^{30}$ Pascual (1987: 11), en un comentario a este pasaje, ya reparó en cómo con esta metáfora se consigue acercar al lector a la realidad que se describe:

Con esta humanización del hogar [refiriéndose a la 'chimenea'] cualquiera está en condiciones de entender lo que se nos intenta explicar, porque se ha hecho el esfuerzo de sustituir los tecnicismos por palabras corrientes referidas a algunas partes del cuerpo humano, que mantienen una relación metafórica con la realidad técnica que están describiendo.

Sin embargo, a pesar de su eficacia expresiva, estos términos no llegan a consolidarse en el uso, pues, como ya señalaba Pascual (1987: 11), con el tiempo, terminan por

${ }^{26}$ «....rehusaré yo las piedras más flacas para el perficionar los cumplimientos, con tal que en toda la espalda de la bóveda, el espinazo y las órdenes que están pegadas al espinazo de una y otra parte, no se pongan en alguna manera, sino de piedra muy dura» (Lozano 1582: 116).

${ }^{27}$ «...el arco consta de compostura de muchos cuños, de los quales, unos con las cabeças de abajo se assientan sobre el mismo arco; otros, assentados en la espalda, tienen el ñudo de el espinazo; otros cumplen la demás redondez de los costados» (Lozano 1582: 85)

${ }^{28}$ Francisco Lozano emplea para clave el término cuño, procedente de cuneum, del texto de Leon Battista Alberti. Cf. Alberti (1486: III, XIII, 235) y Lozano (1582: III, XIII, 85).

${ }^{29}$ «Y el cuño más alto, que se dize espinazo, estará labrado con los demás, assí el arco como las líneas iguales» (p. 115).

${ }^{30}$ Cabeza aparece con la variante cabeça. 
hacerse incomprensibles para quienes no tienen nada que ver con la construcción. Para éstos, tan poco transparentes son hoy los canes o las tijeras como lo pueda ser un dintel o una cornisa, vocablos todos cuya comprensión dependerá de la extensión que tengan al uso común de la lengua y no de su origen.

A esta dificultad habría que añadir que las voces propuestas por Alberti y por Lozano, a pesar de cumplir su función pedagógica y cognoscitiva, ya que ayudan a entender el arte como una emulación de la belleza de la naturaleza, no podían ser viables como tecnicismos por su vaguedad. Un mismo término metafórico, como hueso o nariz, se aplica a distintos elementos arquitectónicos, pues hueso es todo aquello que sustenta un edificio (una columna, un pilar, unos fundamentos...) y nariz se refiere a distintos tipos de salida de aire o, incluso, al lugar por donde evacuar la humedad de las paredes.

Diego de Sagredo, aunque en menor medida que Alberti y Lozano, también optó por emplear metáforas expresivas de significado poco específico. Además del ya mencionado caso de tuétano, emplea el término hueso para referirse a la 'parte interior y más dura de un elemento arquitectónico’ que no debe dañarse con la decoración que se le pueda aplicar:

Todos los miembros y molduras de las basas sobredichas se pueden labrar de follajes, conchas, fenestras, escamas, espichios, vergas, y de otros muchos atavíos a voluntad del discreto maestro, empleando en cada moldura la labor que más le convenga, con tanto que no se disforme el huesso y fación de la moldura (Sagredo 1526: 44).

Y guarda bien que por formar estas labores no desformes la pieça, ca deves guardar entero su huesso y medida, como haze el buen ymaginario, que, quando forma el trapo, guarda con mucho cuydado la carne (Sagredo 1526: 70-71).

Sin embargo, en el proceso de difusión de los términos metafóricos arquitectónicos creados o adoptados durante el Renacimiento sólo acabarán por consolidarse aquellos que logran lexicalizarse (por catacresis) con un significado muy especializado ( $c f$. Villar Díaz, 2001), de modo que la metáfora deja de ser un recurso voluntario y el símil que originó el vocablo resulta ya irreconocible para la mayoría de hablantes. Una prueba de la imposibilidad de que arraiguen en el lenguaje técnico y científico las metáforas creativas se encuentra, por ejemplo, en que entre los repertorios lexicográficos modernos especializados en términos de arquitectura, sólo Vera (2004) recoge la forma hueso.

\section{LOS TÉRMINOS METAFÓRICOS EN LOS TRATADOS DE SAGREDO, URREA Y LOZANO}

Como ya se ha advertido al tratar sobre la terminología en las fuentes de los tratados de Diego de Sagredo, Miguel de Urrea y Francisco Lozano, la presencia de voces metafóricas en los textos españoles se debe, por un lado, a la adopción de una terminología propia de la Antigüedad clásica y, por otro, a la asimilación del procedimiento humanista de emplear símiles entre las construcciones arquitectónicas y formas conocidas del mundo natural o de la vida cotidiana (como son los objetos que rodean al hombre). La mayor parte de los términos metafóricos evoca una realidad con la que el elemento arquitectónico mantiene una relación de similitud basada en la forma (sobrecejo, 'dintel'), el lugar (cabeza de la columna, 'parte superior, capitel') o la función (pedestal, que, como el pie, tiene la función de sostener un cuerpo, la columna). 


\subsection{TipologíA}

Entre los términos metafóricos es posible establecer una clasificación según los conceptos evocados. Ésta contribuye a comprender mejor la concepción de la Arquitectura renacentista. Es posible distinguir cuatro grandes áreas semánticas en las que pueden incluirse todas las voces metafóricas que he podido rastrear en los textos de Sagredo (1526), Urrea (1582) y Lozano (1582). Los vocablos se refieren a: 1) el cuerpo humano y sus acciones; 2) la naturaleza; 3 ) los objetos y sus cualidades, y 4) las formas geométricas.

\subsubsection{Términos antropomórficos}

En todos los textos estudiados se encuentran pasajes que recuerdan el principio filosófico de la arquitectura renacentista: el ideal helenístico según el cual «el hombre es la medida de todas las cosas». ${ }^{31}$ Según este principio, la figura humana es el punto de referencia en la edificación. De este modo, las medidas para el arte de la construcción son el pie, el rostro, el co$d o \ldots,{ }^{32}$ y a partir de ellas se establece el tamaño adecuado de las construcciones. ${ }^{33}$ Un ejemplo significativo de este procedimiento se encuentra en la composición de los distintos órdenes de columnas, que se distinguen por el número de rostros de hombre o de mujer que conforman su altura, que, de forma proporcional, equivale a la estatura humana. El símil se extiende a la denominación de los distintos elementos de la columna mediante términos que se refieren a partes del cuerpo humano:

\footnotetext{
${ }^{31}$ Para el desarrollo de los orígenes del antropocentrismo y su fortuna durante el humanismo, véase Rico (1986).

${ }^{32}$ Sánchez Martín (2005: 18-19) ha estudiado la presencia de términos de medición antropomórficos en los textos reunidos en Mancho Duque y Quirós García (2005).

${ }^{33}$ «Luego, si la naturaleza de tal manera compuso el cuerpo del hombre, que los miembros en su proporción correspondan a toda la figura y grandeza, parece los antiguos aver ordenado con causa y razón que también en las obras aya perfectión de medida de cada uno de los miembros a la universal forma de la figura. [...] También las razones de las medidas, las quales parece ser necessarias en todas las obras, coligieron de los miembros del cuerpo, assí como el dedo, el palmo, el pie, el cobdo, y distribuyéronlas en número perfecto, al qual dizen los griegos telior» (Urrea 1582: $35^{\mathrm{r}}-35^{\mathrm{v}}$ ).
} 


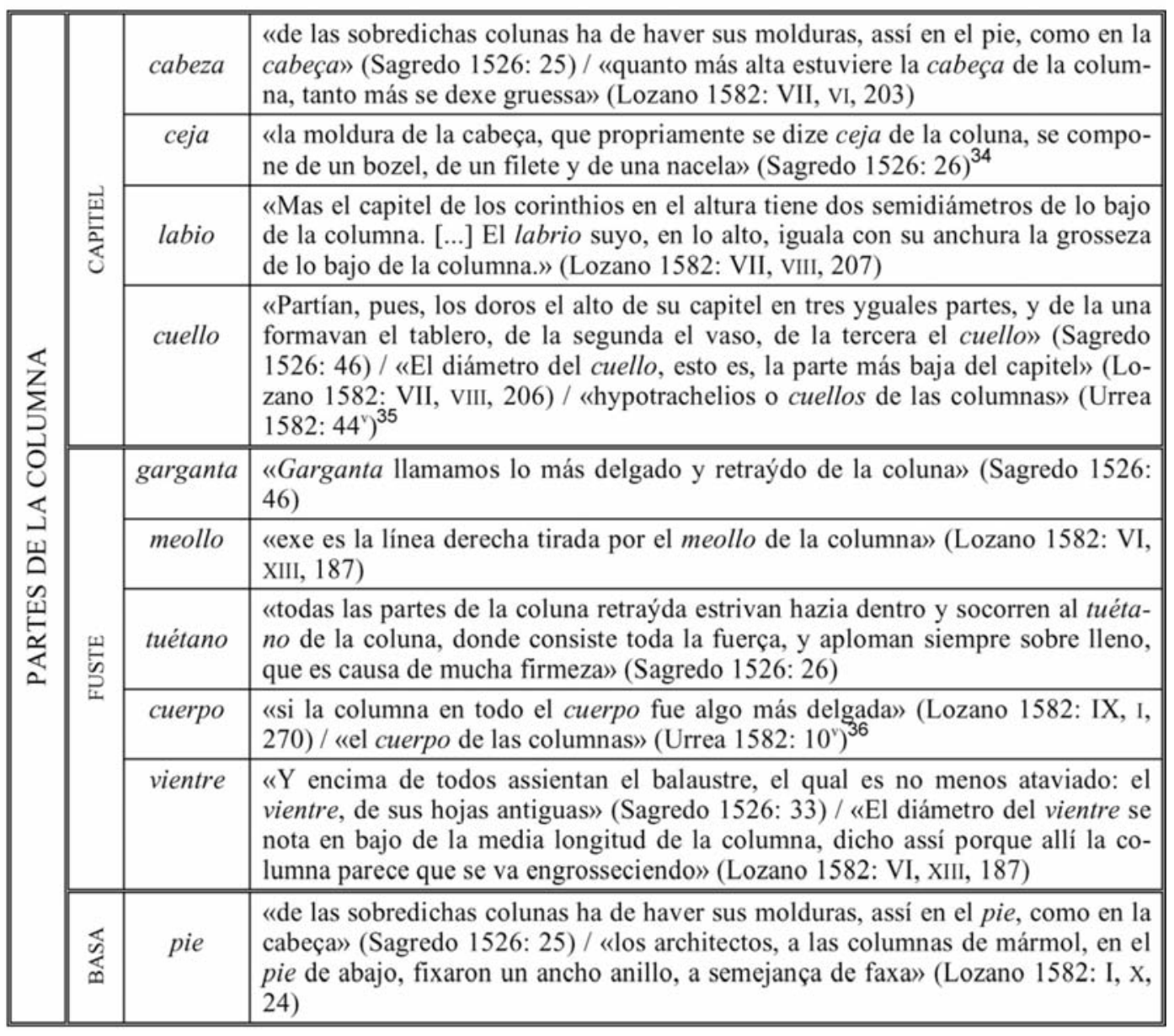

Además de estos términos, a las columnas se aplican otras voces metafóricas referidas a las molduras que pueden encontrarse bien como decoración del capitel o de la basa o bien en otros elementos arquitectónicos del edificio, como la cornisa. Así, gola o gula, según Sagredo (1526), es «una moldura que tiene dos corvos, contrarios el uno del otro. Su figura quiere semejar a la garganta del hombre, la qual en latín se dize gula, por donde es de los antiguos assí llamada» (1526: 17-18), y talón, es también una moldura que recibe este nombre por tener

${ }^{34}$ El término también se documenta en el tratado de Juan de Arfe y Villafañe (1585-1587: 20 r): «El gruesso del capitel, por sobre el bocelino o ceja de la coluna, es el mismo de la coluna por aquella parte.».

${ }^{35}$ En el Vocabulario final aparece también una entrada en la que se define «Hypotrachelio: el cuello de la columna».

${ }^{36}$ En este pasaje Urrea alaba la simetría de las columnas como una característica que las equipara al cuepo humano: «Assimesmo, symmetría es un consentimiento conveniente de todas las partes apartadas a la especie de la universa figura de la rara parte, un respondimiento como el cuerpo del hombre desde el cobdo, el pie, el palmo, el dedo, y de todas las otras partes se halla symmetría, que es medida. Assí se halla en las perfeciones de las obras, principalmente en los templos sagrados, como es el cuerpo de las columnas o del triglipho...» (Urrea 1582: 10v). 
una forma parecida a la del tobillo del hombre. ${ }^{37}$ Además, en las columnas se hallan numerosos elementos decorativos cuya denominación está motivada por la similitud con un objeto o forma geométrica.

En la descripción de las distintas partes de los edificios son también muy frecuentes los símiles de carácter antropomórfico, ya que se concibe la construcción como un cuerpo conformado por miembros. Lo más común es que los términos que se aplican a algunas partes de la edificación vengan determinados por la posición que ocupan. Así ocurre con:

\begin{tabular}{|l|l|}
\hline cabeza & $\begin{array}{l}\text { 'parte superior de un elemento arquitectónico', vg. de una columna (Sagredo 1526: 25; } \\
\text { Lozano 1582: VII, VI, 203) o de un templo (Lozano 1582: VII, IV, 199) }\end{array}$ \\
\hline calva & 'parte alta y lisa de una moldura' (Sagredo 1526: 18 y 46) \\
\hline costados & $\begin{array}{l}\text { 'parte lateral de una construcción', vg. de una bóveda (Lozano, 1582: III, XIII, 85) o de } \\
\text { un puente (Lozano 1582: VIII, vI, 248) }\end{array}$ \\
\hline costra $^{38}$ & $\begin{array}{l}\text { 'superficie que recubre el suelo, pavimento', 'recubrimiento de las paredes' (Lozano } \\
1582: \text { III, vIII, 75), 'superficie que recubre el techo, techumbre' (Lozano 1582: III, XV, } \\
89 \text { y 90) }\end{array}$ \\
\hline frente & $\begin{array}{l}\text { 'parte anterior de un elemento arquitectónico', vg. de un tablero ['ábaco'] (Sagredo } \\
1526: 53) \text { o de un templo (Urrea 1582: 37r) }\end{array}$ \\
\hline rostro & $\begin{array}{l}\text { 'perfil de una moldura' (Sagredo 1526: } 18 \text { y 38) } 39 \\
\text { tectónico', vg. un tímpano (Urrea 1582: } 122 \text { ) }\end{array}$ \\
\hline
\end{tabular}

En estos casos, una misma palabra puede referirse a realidades distintas, pues los términos no identifican un objeto, sino su localización dentro de un edificio. Las voces metafóricas que propiamente designan elementos arquitectónicos concretos, con una forma y una función determinadas, quedan ejemplificadas con las palabras referidas a las distintas partes de una columna. Además, se encuentran otros términos como boca, 'respiradero de una chimenea' (Lozano 1582: V, XVII, 154); degolladura, 'parte más delgada del vaso de un balaustre' (Sagredo 1526: 33 y 34); dentellón, 'adorno del friso en forma de dientes' (Sagredo 1526: 65 y Lozano 1582: 205 y 211); nariz, 'conducto para evacuar aire o agua' (en el primer caso, Lozano 1582: 99, y Urrea 1582: 95v' en el segundo, Urrea 1582: 95'); sobrecejo, 'dintel' (Urrea 1582: 55' $56^{\mathrm{r}}$ y $143^{\mathrm{r}}$ ); ojo, 'espacio circular vacío en el interior de una escalera de caracol' (Lozano 1582: 207); ombligo, 'centro de una traza en espiral' (Sagredo 1526: 48), y 'asidero que, en las piedras sillares, facilita su transporte' (Lozano 1582: 178); y, por último, los derivados de pie, como peana, pedestal y podio.

Finalmente, y como ya se ha expuesto, en la traducción de Francisco Lozano se encuentran muchos términos antropomórficos cuyo significado denotativo resulta difícil de de-

\footnotetext{
${ }^{37}$ Véase más arriba el ejemplo de talón, ya mencionado en Sagredo (1526: 19).

${ }^{38}$ En el texto de Francisco Lozano se muestra la preferencia por el término costra respecto del sinónimo corteza: «Nós hazemos las costras (por llamarlas assí, antes que no cortezas)» (Lozano 1582: III, XI 81).

${ }^{39}$ A pesar de la definición de rostro que ofrece el DRAE desde su edición de 1956 hasta la de 2001, como voz desusada que equivale a 'frente de una moldura', en Sagredo, que acompaña sus definiciones de ilustraciones que así lo demuestran, equivale a 'perfil'. $C f$. Sagredo (1526): «Bozel es otra moldura que su rostro es de buelta redonda, la qual se llama por otro nombre rudón, de rudens, vocablo latino, que quiere dezir 'maroma' o 'soga gruessa'» (p. 18) y «Echino es otra moldura que se pone sobre el plinto en lugar de murezillo y su rostro es como medio bozel» (p. 38).
} 
terminar. Además de las voces ya comentadas, referidas a la estructura del edificio, se emplean vocablos relacionados con los métodos de construcción que muestran una voluntad de transmitir la idea de que la edificación se realiza a imagen de la figura humana. Un ejemplo muy significativo se halla en la declaración de que la pared debe contar con brazos y manos, las piedras, que a imagen de los miembros anatómicos extendidos sustenten el muro:

Luego éste [el edificio] tendrá piedras muy duras y en longitud muy prolixas, que se estiendan por el largo de las paredes, a manera de braços y de manos; y estas piedras serán anchas según la grosseza de la pared, de suerte que no sea necessario ningún repleno (Lozano 1582: 74).

Principalmente, conviene que se estiendan manos, que es algunas piedras de la una y de la otra parte, como por ayudas, para sustentar los cumplimientos de la otra pared (Ibídem).

No obstante, en el lenguaje de la arquitectura renacentista, la identificación entre los elementos constructivos y la figura humana no se limita al empleo de términos anatómicos. Las acciones y cualidades del hombre relacionadas con la indumentaria y la elegancia sirven para designar aspectos de la ornamentación de los edificios. En este sentido, el tratado de Diego de Sagredo ofrece la primera documentación del adjetivo galano aplicado a elementos arquitectónicos:

te hago saber que lo más galano e vistoso del edificio son las molduras que le ponen, bien assí como lo mejor de tu chamarra son las tiras y tirillas de seda que tiene (1526: 17).

El CORDE ofrece otros ejemplos de fecha posterior, como el «galano patio» de Pedro Hernández de Villaumbrales (Peregrinación de la vida del hombre, 1552) o el «sepulchro sumptuosíssimo y galano» de un romance anónimo («Romance», en Rosa gentil. Tercera parte de romances de Joan Timoneda, 1573). En el corpus de textos de ciencia y técnica en el Renacimiento, compilado en Mancho Duque y Quirós García (2005), la obra de Joan de Arfe y Villafañe menciona unos «frontispicios muy galanos» (De Varia Commesuración para la Esculptura y Architectura, 1585-1587) y Alonso de Vandelvira aplica el término a una escalera («Esta escalera es la más galana y artista que yo e hallado», Libro de traças de cortes de piedras, 1591).

En los tres tratados estudiados se emplean también verbos como ataviar y vestir, referidos a la acción de decorar elementos arquitectónicos. Diego de Sagredo alude a que los arquitectos de la Antigüedad, «Halladas y formadas las dichas molduras, procuraron para mayor elegancia de adornarlas y ataviarlas de diversas labores» (1526: 21), ${ }^{40} \mathrm{y}$, al tratar de los capiteles jónicos, afirma que «Los miembros d'este capitel se atavían y adornan de muchas maneras» (p. 49). Vestir lo emplea para los vasos de las columnas, «cubiertos y vestidos de follagería y otras labores fantásticas» (p. 33); y Lozano, para las paredes, en el epígrafe «Del vestir las paredes de los palacios, y de el calentar los lugares, y del reformar y emendar los vicios de las mismas paredes» (1582: IX, XIII, 342), donde la humanización de los muros llega a tal grado que éstos tienen incluso vicios.

${ }^{40}$ En la misma página se documenta ataviar en otra ocasión: «los de Corinthio fueron los primeros que ataviaron las dichas molduras con labores y hojas» (Sagredo 1526: 21). 


\subsubsection{Términos referidos a la naturaleza}

Las voces metafóricas referidas a elementos naturales, fundamentalmente animales y plantas, son más escasas que el léxico antropomórfico. Algunas simplemente identifican un elemento con la realidad que evocan. Así ocurre, por ejemplo, con las hojas, tallos y cogollos que embellecen los capiteles corintios, en un tipo de ornamentación que recibe el nombre de follaje (Sagredo 1526: 44 y 61) y follajería (Sagredo 1526: 33):41

Las hojas que se esculpen y forman alderredor d'este vaso comiençan del assiento, y las primeras suben un tercio, y las segundas otro, los cogollos y tallos ocupan el otro (Sagredo 1526: 51). También los animales aparecen como elementos decorativos:

En los cantones, otrosí, d'esta basa se esculpen y forman pies de grifos, garras de leones y de mastines, y de otras bestias muy feroces (Sagredo 1526: 35).

En el diálogo de Sagredo es especialmente abundante este tipo de voces, pues se enumeran numerosos adornos que, según Marías y Bustamante, están

en clara consonancia con el imperante estilo ornamental «plateresco», al que va a dar medidas; siendo este estilo una decoración «a la romana», tratada a la manera del tardogótico español, y aplicada sobre estructuras todavía góticas. En este sentido, Sagredo llega a aceptar el ornato de todos los elementos arquitectónicos con «follages, conchas, fenestras, escamas, espichios, vergas... [porque]... no hay arte donde así se puedan emplear las obras de natura y fantasías del hombre como la romana», en una toma de posición de naturalismo mal entendido (1986: 10).

En algunos casos, los términos metafóricos evocan tan sólo la forma natural que recrea un elemento arquitectónico. Así ocurre con la media caña, 'estría de la columna' (Sagredo 1526: 30) o 'moldura semicircular' (Sagredo 1526: 18 y Urrea 1582: 57 y 139r), ${ }^{42}$ la «escalera en caracol» (Lozano 1582: 71), las crestas, decoraciones de forma puntiaguda (Sagredo 1526: 33 y Lozano 1582: 246 y 279), y el papo de paloma (Sagredo 1526: 17-18), voz patrimonial ${ }^{43}$ para designar una moldura con una parte superior cóncava y una inferior convexa. ${ }^{44}$

Finalmente, un tipo de metáfora bastante productivo consiste en el uso de términos referidos a partes de plantas o de árboles. Tal y como ocurría con los órganos del cuerpo humano,

${ }^{41}$ Aparece con la variante follagería. Terreros (1786-1793) equipara este tipo de decoración al brutesco o grutesco: «FOLLAJE, en la Arquitectura, especie de adorno de cogollos, hojas harpadas, sátiros y otros animales, por lo cual le dan asimismo el nombre de brutesco, y el de grutesco, por haber hallado esta especie de adorno en algunas grutas y subterráneos de Roma, V. Pal.» (s. v.). En los textos reunidos en Mancho Duque y Quirós García (2005) sólo aparece grutesco en el texto de Juan de Arfe y Villafañe (Varia conmensuración para la escultura y arquitectura, 1585-1587, fols. $10^{\mathrm{r}}$ y $33^{\mathrm{r}}$ ).

${ }^{42}$ Juan de Arfe y Villafañe también emplea el término caña para referirse al fuste de la columna. Distingue, además, entre caña alta ('parte superior del fuste') y caña baja ('parte inferior del fuste').

${ }^{43}$ «Esta moldura es dicha por los griegos syma, y por los modernos papo de paloma» (Sagredo 1526: 17-18).

${ }^{44}$ Equivale a la designación más moderna talón reverso, según el Diccionario de las nobles artes para instrucción de los aficionados y uso de los profesores de Diego Antonio Rejón de Silva (1788), s. v. papo de paloma ('lo mismo que talón reverso'), que, a su vez, se define, s. v. talón reverso, como 'el talón quando está encima la parte cóncava y abajo la convexa'. 
se identifican ciertos elementos arquitectónicos con miembros de los vegetales porque comparten similitudes referidas a la forma que tienen, a la función que desempeñan y al lugar que ocupan:

\begin{tabular}{|c|c|c|}
\hline follaje & $\begin{array}{l}\text { 'adorno de cogollos y hojas harpadas } \\
\text { con que se guarnece y adorna alguna } \\
\text { obra' } \\
\text { (Diccionario de Autoridades, s. } v \text {.) }\end{array}$ & $\begin{array}{l}\text { «Todos los miembros y molduras de las basas } \\
\text { sobredichas se pueden labrar de follajes» } \\
\text { (Sagredo 1526: 44) }\end{array}$ \\
\hline follajería & 'follaje' & $\begin{array}{l}\text { «buxetas y vasos antiguos, diversamente } \\
\text { formados, cubiertos y vestidos de follagería y } \\
\text { otras labores fantásticas» (Sagredo 1526: } 33 \text { ) }\end{array}$ \\
\hline corteza & $\begin{array}{l}\text { 1. 'cabezal de capitel jónico, o ele- } \\
\text { mento compacto horizontal, situado } \\
\text { bajo el tablero o ábaco, que enlaza } \\
\text { una voluta con otra' (Vera 2004: } \\
\text { s.v.) } \\
\text { 2. 'recubrimiento de techos, suelos y } \\
\text { paredes }\end{array}$ & $\begin{array}{l}\text { «Contentoles, otrosí, la invención del vaso } \\
\text { [...] y le fingieron estar cubierto con una } \\
\text { gruessa corteza, tan luenga, que los cabos que } \\
\text { de una parte y de otra caýan, se rollavan de sí } \\
\text { mesmos como piel de pargamino» (Sagredo } \\
1526: 47 \text { ) / «señalarás, assimesmo, otros dos } \\
\text { puntos, que serán centros de la buelta de la } \\
\text { corteza» (Sagredo 1526: } 48 \text { ) } \\
\text { «la corteza de fuera [del templo], según la } \\
\text { costumbre de los antiguos, será aprovada de } \\
\text { cal entreverada de figuras» (Lozano } 1582 \text { : } \\
214 \text { ) / «el suelo y las texas son la corteza } \\
\text { postrera de fuera» (Lozano } 1582: 82 \text { ) }\end{array}$ \\
\hline tronco & 'fuste de la columna' & $\begin{array}{l}\text { «el tronco de la columna estriado» (Urrea } \\
1582: 47^{v} \text { ) }\end{array}$ \\
\hline raiz & 'cimientos' & $\begin{array}{l}\text { «si el suelo no se diere fixo, }[\ldots] \text { en ciertos } \\
\text { lugares }[\ldots . .] \text { junto a las raýzes de la pared, }[\ldots] \\
\text { se fixarán palos en el suelo muy espessos» } \\
\text { (Lozano } 1582: 345)\end{array}$ \\
\hline
\end{tabular}

En el caso de hiedra, término que Lozano (1582) propone como sinónimo de óvolo, la relación metafórica entre el elemento natural y el ornamental se fundamenta sólo en la función, la capacidad de ambos para adherirse a una superficie, y no en la forma, que es oval:

El óvolo he dudado si se llamasse yedra, porque está pegado, estendido, y el lineamento de su relieve es como la letra $C$, pegado en bajo la letra $L$, d'esta manera: $L c$. (Lozano 1582: 205).

\subsubsection{Términos que evocan objetos}

Las metáforas que designan elementos arquitectónicos mediante símiles con objetos de la vida cotidiana guardan una estrecha relación con la concepción del hombre como punto de referencia esencial en la teoría renacentista de la construcción. Así lo demuestra el hecho de

${ }^{45}$ En este sentido, el término es sinónimo de costra, como se muestra en el epígrafe de Lozano (1582: III, XI, 79): «Del untar la pared y también del vestirla con cortezas y costras, ley antiquíssima de los architectos que se ha de guardar como oráculo». 
que la mayor parte de estas voces se refiera a piezas del vestido humano. Los hiperónimos armadura y vestimenta designan, respectivamente, la 'estructura que aguanta una edificación mientras se construye' (Lozano 1582: 216) y la 'decoración que recubre los muros' (Lozano 1582: 213). En los tratados las denominaciones de distintas prendas de ropa identifican elementos arquitectónicos: faja, 'moldura ancha' (Sagredo 1526: 47 y Lozano 1582: 208), fal$d a,{ }^{46}$ 'ancho de la moldura' (Sagredo 1526: 71), y zapata, 'pieza que sustenta una viga, hecha de piedra' (Lozano 1582: 82) o 'de madera' (Urrea 1582: 89'). Diversas molduras aparecen representadas mediante dos voces que, en su sentido no figurado, se refieren a alhajas: la corona $^{47}$ (Sagredo 1526: 18 y Lozano 1582: 186) y el anillo (Lozano 1582: 87 y Urrea 1582: $139^{r}$ ), 'moldura [semicircular] que circunda la coluna por la parte superior debajo del capitel' (Terreros 1786-1793: s. v.) y que además puede encontrarse en la basa (Lozano 1582: 24). Incluso, un complemento, el bastón, designa el 'barrote de una reja' (Sagredo 1526: 36) y una 'moldura' (Lozano 1582: 250 y 264), que aparece también con los nombres de bastoncillo (Lozano 1582: 109 y 205) y bastonciño (Lozano 1582: 251). ${ }^{48}$

En algunas ocasiones, los objetos evocados forman parte del utillaje humano, como la mesa (Sagredo 1526: 46 y 70), 'superficie que ocupa un elemento arquitectónico', o el tablero (Sagredo 1526: 46 y Urrea 1582: 42v'), 'ábaco', y el vaso, 'capitel' (Sagredo 1582: 46, $49^{49}$ y $50)$.

\subsubsection{Términos relativos a formas geométricas}

El último de los cuatro campos semánticos en los que pueden englobarse los términos metafóricos de los tratados de Sagredo, Lozano y Urrea es el de la Geometría. Es comprensible que esta disciplina sirva de fuente para algunas voces, pues el diseño arquitectónico es, al fin y al cabo, la combinación de formas geométricas. La idea de que el arquitecto debe conocer los saberes de la Geometría se encuentra en Virtuvio y, de ahí, pasó al resto de tratados:

nota que el buen architeto se debe proveer, ante todas cosas, de la sciencia de Geometría, de la qual escrivieron muchos autores (Sagredo 1526: 14).

Esto principalmente se deve guardar en aquella arte, que perfectamente no se puede saber medianamente sin saber las otras artes, como es el arte y officio de Architectura, para el qual officio se requiere tener noticia de todas las demás sciencias: de Philosophía Moral y Natural, Geometría, Arithmética, Perspectiva, Música, Astrología y Derechos (Urrea 1582: Epistola al lector, fol. $3^{v}$ ). Y, assí, el que quisiere ser perfecto architecto, como dixo Vitrubio, conviene que tenga prática theórica, sepa Arithmética, Geometría, conozca las tres partes en que la dicha sciencia se divide, qu'es machinatoria, gnomónica y edificatoria (Lozano 1582: V).

\footnotetext{
${ }^{46}$ Aparece con la variante halda.
}

${ }^{47}$ Diego de Sagredo justifica la designación de corona con estas palabras: «Llámase corona porque, antiguamente, con esta moldura coronavan todo el edificio alderredor. Dízese también corona porque no es menos eminente entre las otras molduras, como la corona en la cabeça de rey o príncipe» (1526: 18).

${ }^{48}$ El diccionario de Terreros (1786-1793) sólo registra la forma bastoncino. Los términos bastoncillo y bastonciño no se recogen en ningún repertorio lexicográfico y es posible que, en el caso de bastonciño, la presencia del diminutivo se deba a la atracción de la voz collarino. $C f$. «lo que se ajunta en los altos trozos de las columnas tendrá un bastonciño y un collarino» (Lozano 1582: 251) y «esta novena parte se dividirá en nueve partecillas menudas, [...] una darás al bastonciño y collarino» (Ibídem).

${ }^{49}$ Aparece con la variante baso. 
Asimismo, la vocación pedagógica de los textos estudiados justifica que en ellos se encuentren pasajes dedicados a la explicación de los rudimentos de la Geometría. Diego de Sagredo (1526: 13-16) incluye un capítulo titulado «De algunos principios de geometría necessarios y muy usados en el arte del traçar» y Leon Battista Alberti trata de las áreas y líneas en el Libro I, capítulos VII y VIII, que, en la traducción de Francisco Lozano (1582), reciben, respectivamente, los epígrafes «De la área y de las especies de las líneas» (p. 17) y «Las especies, forma y figura de las áreas, y quáles d'ellas sean más útiles y más firmes» (p. 21)..$^{50}$

En el interior de los tratados, la forma geométrica de algunos de los elementos' arquitectónicos condiciona su denominación. Así ocurre en el diálogo de Sagredo con las volutas centrales del orden corintio, que reciben el nombre de hélices, voz procedente del griego $\ddot{\lambda} \lambda\llcorner\xi$, -tXos, 'espiral':

Y nota que la mayor parte de su diferencia consiste en las asas de los vasos, que propriamente se llaman hélyces (Sagredo 1526: 56-57).

La línea espiral también sirve para denominar las basas de las columnas:

Espiras llamavan los antiguos a las basas de las colunas, que quieren dezir 'bueltas de circulación'(Sagredo 1526: 37).

La relación existente entre el óvolo (Lozano 1582: 205), 'moldura redonda cuio perfil es por lo común un cuarto de círculo’ (Terreros 1786-1793: s. v.) y su forma elíptica propicia que esta voz aparezca en muchos casos bajo la forma óvalo (Lozano 1582: 205, 208 y 225). En este sentido, el $D C E C H$ ya señalaba que el término óvolo, tomado del italiano, pasó a óvalo por «influjo semántico y quizá fonético del adj. oval»». ${ }^{51} \mathrm{Y}$, por último, las superficies lisas de las edificaciones reciben en Sagredo el nombre de planos (Sagredo 1526: 45 y 69).

\subsection{FUENTES}

Los tratados de Sagredo, Urrea y Lozano testimonian el proceso de adopción de términos metafóricos procedentes del léxico de la construcción grecolatina, así como la gestación de voces en español mediante el mismo recurso a la analogía. De las palabras metafóricas a las que me he referido a lo largo de este estudio - un total de setenta y seis-, he podido encontrar el equivalente latino de quince de ellas en el De architectura de Vitruvio, valiéndome del diccionario de Callebat y Fleury (1995):

${ }^{50}$ En el De re aedificatoria los capítulos de cada uno de los diez libros que lo conforman no van encabezados por epígrafes. Éstos aparecen en la traducción de Cossimo de Bartoli que consultó Lozano y, de ahí, pudo tomar la idea de rubricar los capítulos. Lozano no traduce literalmente los títulos de Bartoli, aunque parece que se inspira en ellos. $C f$., por ejemplo, Libro I, cap. II: «De la occasione del fare gli edificii \& in quante parti consista tutto il modo dello edificare \& quali cose sieno utili a ciascuna di esse parti» (Bartoli 1550: 10) / «Los principios de los assientos o edificios, seys partes: región, área o planta, partición, pared, techo, abertura, y tres cosas que convienen a cada una de estas partes, que son: salud, firmeza y recreación» (Lozano 1582: 6).

${ }^{51}$ Óvolo y óvalo fueron formas coetáneas en la época de Lozano. El DCECH (s. v. huevo) documenta por primera vez óvalo en el Tesoro de Sebastián de Covarrubias (1611) y óvolo en el Diccionario de Autoridades; de ahí que señale que la forma óvalo es más antigua que óvolo. 


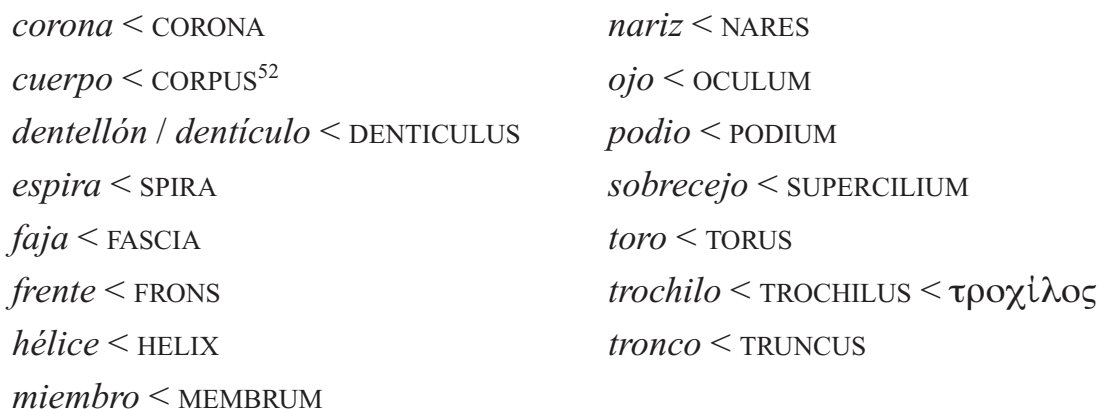

Las voces del texto de Francisco Lozano (1582) que sólo se documentan en este tratado proceden de la traducción de los términos de Leon Battista Alberti. Así ocurre, por ejemplo, con los vocablos referidos a las estructura de la edificación y a su embellecimiento mediante el recubrimiento de las paredes:

\begin{tabular}{|c|c|c|}
\hline corteza & $\begin{array}{l}\text { «Mas no prohibiré yo que la corteza } \\
\text { de dentro, juntamente con la frente, } \\
\text { toda su pared la cubras de más blan- } \\
\text { da piedra» (III, VIII, } 75 \text { ) }\end{array}$ & $\begin{array}{l}\text { "At corticem intestinum una cum tota sui parietis } \\
\text { facie molliori ducas lapide non vetabo» (III, VII, } \\
206-207 \text { ) }\end{array}$ \\
\hline costra & $\begin{array}{l}\text { «que la costra que le aplicares [a la } \\
\text { pared] o el emblanquimiento sea obra } \\
\text { que no se pueda deshazer» (III, vIII, } \\
75 \text { ) }\end{array}$ & $\begin{array}{l}\text { «ut quan adegeris seu crustam seu albarium, } \\
\text { indelebile opus praestetur» (III, vIII, 207) }\end{array}$ \\
\hline $\begin{array}{c}\text { espalda } \\
\text { ñudo } \\
\text { del } \\
\text { espina- } \\
\text { zo }\end{array}$ & $\begin{array}{l}\text { «ya conviene confessar que el arco } \\
\text { consta de compostura de muchos } \\
\text { cuños, de los quales, unos con las } \\
\text { cabeças de abajo se assientan sobre el } \\
\text { mismo arco; otros, assentados en la } \\
\text { espalda, tienen el ñudo del espinazo; } \\
\text { otros cumplen la demás redondez de } \\
\text { los costados» (III, XIII, 85) }\end{array}$ & $\begin{array}{l}\text { «ut iam fateri oporteat arcum ipsum cuneorum } \\
\text { plusculorum compactione constare, quorum alii } \\
\text { capitibus infimis ad arcum ipsum subsideant, alii } \\
\text { ad dorsum insidentes nodum spinae obtineant, } \\
\text { alii reliquum expleant ambitum costarum» (III, } \\
\text { XIII, 235) }\end{array}$ \\
\hline hueso & $\begin{array}{l}\text { «las qualescosas todas vienen nom- } \\
\text { bramiento de huessos» (III, vI, 71) }\end{array}$ & $\begin{array}{l}\text { «quae omnia ossium appellatione veniunt» (III, } \\
\text { VI, 195) }\end{array}$ \\
\hline $\begin{array}{l}\text { nervio } \\
\text { atadura }\end{array}$ & $\begin{array}{l}\text { «los affirmaremos muy bien [los } \\
\text { huesos] con nervios y ataduras» (III, } \\
\text { XII, 84) }\end{array}$ & $\begin{array}{l}\text { «ossa ossibus coniugemus et nervis illigamentis } \\
\text { que bellissime affirmabimus» (III, XII, 233) }\end{array}$ \\
\hline ligadura & $\begin{array}{l}\text { «Pero de huessos a huessos se esten- } \\
\text { derán ligaduras» (III, XIV, 87) }\end{array}$ & $\begin{array}{l}\text { «Ab ossibus vero ad ossa illigamenta protrahen- } \\
\text { tur» (III, XIV, 243) }\end{array}$ \\
\hline raiz & $\begin{array}{l}\text { «allí, junto a las raýzes de la pared» } \\
(\mathrm{X}, \mathrm{XVII}, 345)\end{array}$ & «hinc ad radices parietis» (X, XVII, 993) \\
\hline
\end{tabular}

${ }^{52}$ En latín y en español tiene las acepciones de 'fuste de una columna' y 'edificación'. 
Como puede observarse en los ejemplos anteriores, Francisco Lozano opta, en ocasiones, por traducir un término como illigamentum de diversas formas, atadura y ligadura. Otras veces, en cambio, el propio texto de Alberti ofrece ya dos sinónimos para una misma realidad, como ocurre con el recubrimiento de las paredes, que recibe los nombres de corticea y crusta, traducidos por corteza y costra.

Aunque no es frecuente, a veces Lozano adopta términos latinos de la obra de Alberti, caso de ren, latinismo frecuente en la lengua romance de la época: ${ }^{53}$

«Pero los cuños segundos, que se levantan cercanos sobre estos primeros, si fueren de piedra grande, procura que ambos y uno esté pegado al otro, juntadas las renes en línea) (III, XIII, 86) ${ }^{54}$

«Esta parte de pared maciza occupará las renes de los assientos» (VIII, IX, 263)
«Qui vero secundi proximi in hos primos insurgent cunei, si praegrandi erunt ex lapide, curato ambo alter ad alterum suis hereat iunctis ad lineam renibus.» (III, XIII, 239)

«Hanc solidi parietis partem occupabunt subselliorum renes》 (VIII, IX, 763)

Además, el hecho de que el traductor al español consultara la versión de Cossimo Bartoli provocó la inclusión de italianismos, como ya hemos comentado en el caso de collarino por nextrum.

Así pues, en los tres tratados estudiados, la fuente principal para los términos arquitectónicos metafóricos es el latín. Como se ha demostrado, en muchas ocasiones se toman prestados o se traducen tecnicismos latinos, muchos de ellos préstamos a su vez del griego. Se dan casos de calco, por ejemplo, en el empleo por parte de Diego de Sagredo y de Miguel de Urrea de la forma tablero, que equivale al ábaco (del latín abacus, 'tablero para contar' y éste del griego $\check{\alpha} \beta \alpha \xi,-\chi 0 \varsigma$ ), que aparece en los textos de Juan de Arfe y Villafañe (Varia conmensuración para la escultura y arquitectura, 1585-1587) y de Patricio Caxesi Florentino (traducción de la Regla de las cinco órdenes de architectura, de Jacome de Vignola, 1593). En este caso, la voz patrimonial tablero facilita la comprensión del significado, pues tablero y ábaco designan la 'pieza cuadrada en forma de tablilla que [...] corona el capitel y sirve de asiento al arquitrabe, a la vez que protege la decoración de dicho capitel' (Paniagua 1998: s. v. ábaco). Asimismo ocurre con el vocablo grecolatino éntasis (del latín entasis y éste del griego

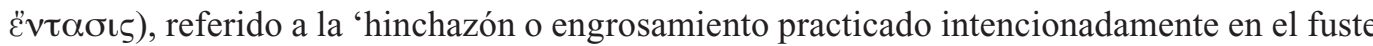
de la columna, a fin de corregir defectos ópticos de perspectiva' (Paniagua 1998: s. v. éntasis). El tecnicismo aparece en los tratados en una sola ocasión y con una errata en un pasaje de la traducción de Miguel de Urrea: «Del augmento que se haze en medio de las columnas, que acerca de los griegos se llama éstasis, se dará razón conveniente en el tercero libro» (1582:

${ }^{53}$ Elia-Mancho (2002: 563, n. 51.50) dan cuenta del término en la obra de San Juan de la Cruz y refieren que éste se halla también en Antonio de Nebrija, Sebastián de Covarrubias, Gonzalo Correas y Francisco del Rosal. El $D C E C H$ documenta por primera vez ren en el Universal Vocabulario de Antonio de Palencia.

${ }^{54}$ En este sentido, 'segunda hilada de dovelas junto al arranque de un arco o bóveda', aparece la voz romance en Vera (2004: s. v. riñones) y también en los repertorios de Fullana (1995: s. v. ronyó) y Paniagua (1998: $s$. v. riñón). Sin embargo, las voces ren o riñón no tuvieron gran difusión, pues no se documentan con un significado referido a la técnica arquitectónica en otros pasajes del Corpus de la Técnica en el Renacimiento ni en los textos del CORDE de los siglos XVI y XVII. 
fol. $\left.41^{\mathrm{r}}\right) .^{55}$ La confusión éstasis por éntasis se debe a la rareza de la palabra, de la cual no se encuentran otras documentaciones en textos castellanos de los Siglos de Oro. ${ }^{56}$ La palabra habitual entre los tratadistas para referirse al éntasis es el término vientre:

Y encima de todos assientan el balaustre, el qual es no menos ataviado: el vientre, de sus hojas antiguas, y el cuello, de sus estrías (Sagredo 1526: 33 ).

Los diámetros de los círculos que se han de considerar son en cinco lugares por la columna. Los nombres de los lugares son éstos: projectura, retractión, vientre (Lozano 1582: VI, XIII, 187). ${ }^{57}$

Además de estos casos de calco semántico, en los que se añade un significado metafórico a una palabra patrimonial, evitando de este modo la incorporación de un tecnicismo grecolatino opaco, en el tratado de Diego de Sagredo se encuentran voces metafóricas que no tienen su origen en el préstamo de tecnicismos procedentes de los textos de Vitruvio o de Alberti, sus fuentes fundamentales. Así ocurre, por ejemplo, con los vocablos:

\begin{tabular}{|c|c|c|}
\hline calva & $\begin{array}{l}\text { deriv. del lat. CALvUs } \\
(D C E C H, s . v . \text { calvo })\end{array}$ & $\begin{array}{l}\text { 'parte superior y lisa de un elemento arquitec- } \\
\text { tónico' (Sagredo 1526: } 18 \text { y } 46)^{58}\end{array}$ \\
\hline ceja & $\begin{array}{l}\text { del lat. CǏLİA }(D C E C H, s . v \text {. } \\
\text { ceja) }\end{array}$ & $\begin{array}{l}\text { 'moldura que forma la parte superior del fuste } \\
\text { de la columna' (Sagredo 1526: 26 y } 34)^{59}\end{array}$ \\
\hline ombligo & $\begin{array}{l}\text { del lat. ŬMBILLICUS ( } D C E C H, s \text {. } \\
\text { v. ombligo) }\end{array}$ & $\begin{array}{l}\text { 'centro de una traza en espiral' (Sagredo } \\
1526: 48 \text { ) }\end{array}$ \\
\hline tuétano & $\begin{array}{l}\text { «variante del antiguo y dialectal } \\
\text { tútano, [...] de la onomatopeya } \\
\text { TUT- o TOT-, imitación de un } \\
\text { sonido de viento» ( } D C E C H, s \text {. } \\
\text { v. tuétano) }\end{array}$ & $\begin{array}{l}\text { 'parte interior y más dura de una columna' } \\
\text { (Sagredo } 1526: 26 \text { ) }\end{array}$ \\
\hline
\end{tabular}

Por último, la presencia de la metáfora en el léxico renacentista de la Arquitectura también puede rastrearse en la lengua de origen de muchos términos prestados de lenguas romances. En algunos casos, el origen metafórico de las voces es opaco, pues el significante no guarda relación con ninguna lexía española. Así ocurre, por ejemplo, con palabras como tondino («del it. tondo, propiamente 'redondo', forma vulgar extraída del it. ant. ritondo», DCECH, s. v. redondo), gola o gula (en su sentido literal, 'garganta', probablemente catalanismo o voz de origen galorromance o italiano, DCECH, s. v. gola) y jamba (del francés anti-

${ }^{55}$ A pesar del anuncio, no se trata acerca de cómo debe realizarse el éntasis; sólo se encuentra, al final del libro III, capítulo 3, una referencia a que «los gruessos de las estrías [de las columnas] han de ser quanto parecerá el augmento en el medio de la columna por la discripción» (fol. $45^{\mathrm{v}}$ ).

${ }^{56}$ Según búsquedas realizadas en el Corpus de la Técnica en el Renacimiento y en el CORDE.

${ }^{57}$ Alberti (1486: VI, XIII, 523) empleó la forma venter y Bartoli (1550: 196) tradujo el término con el equivalente italiano ventre.

${ }^{58}$ En el tratado de Diego de Sagredo (1526), calva se aplica a una moldura, la corona (p. 18) y al tablero del capitel (p. 46).

${ }^{59}$ Esta definición procede de Clairac (1877-1891: s. v. ceja). Juan de Arfe y Villafañe (Varia conmensuración para la escultura y arquitectura, 1585-1587) empleó también el término al referirse al 'bocelino o ceja de la coluna' (fol. 20 ${ }^{\mathrm{r}}$. 
guo jambe, 'pierna', derivado, a su vez, del latín vulgar CAMBA, 'pierna', según el $D C E C H, s$. v. gamba). ${ }^{60}$

En otras ocasiones, en cambio, la metáfora podría ser más reconocible en español, como en los préstamos follaje (tomado del catalán fullatge, o del occitano moderno fouiage, o del francés feuillage, DCECH, s. v. hoja), pedestal (del francés piédestal, y éste del italiano piedistallo, DCECH, s. v. pie) y óvolo / óvalo (del italiano óvolo, DCECH, s. v. huevo).

\section{CONCLUSIONES}

El diálogo humanista de Diego de Sagredo y las traducciones de Miguel de Urrea y de Francisco Lozano contribuyeron a difundir en España los principios de la arquitectura renacentista y, con ellos, un nuevo léxico especializado en el que la metáfora ocupa un espacio fundamental. Prueba de la novedad de los términos introducidos es que la obra de Sagredo, Las medidas del romano (1526), ofrece primeras documentaciones de numerosos tecnicismos, como, por ejemplo, las palabras hélice, gula, papo, pedestal y troquilo.$^{61}$ Las voces metafóricas, como se ha demostrado en este estudio, forman parte de ese legado procedente unas veces de préstamos grecolatinos y otras de la génesis de nuevos términos en castellano o del préstamo de voces romances. La teoría arquitectónica renacentista acogió la metáfora como un procedimiento de creación de una terminología que le permitía identificar elementos constructivos con formas de la naturaleza que pretendía emular. La mayoría de voces metafóricas se refieren al hombre: a las partes de su cuerpo, a sus hábitos (la vestimenta, la galantería...) y a los objetos que le rodean (las joyas, las prendas de vestir, el menaje...), y designan elementos arquitectónicos con una apariencia, una función o una posición análoga a las realidades que evocan. En menor medida, también los animales, las plantas y las figuras de la geometría se ven reflejados en el léxico de la edificación en el Renacimiento.

La metáfora no sólo contribuye a generar una terminología acorde con los preceptos clasicistas que priman en la teoría arquitectónica de la época, sino que también cumple una clara función retórica y didáctica. Sagredo y Urrea recurren a la etimología para tratar de explicar el significante y el significado de algunos tecnicismos y, con ello, recuperan metáforas muertas de numerosos préstamos grecolatinos. El lector consigue así identificar y recordar con mayor facilidad los nuevos términos, que asocia ya a un referente visual. En la traducción de Francisco Lozano se recogen las voces metafóricas que Leon Battista Alberti inventa, cuando es necesario, para hacer más comprensible la técnica arquitectónica.

Debe tenerse en cuenta que los términos metafóricos no cumplen una mera función retórica o estilística, sino que son empleados por los tratadistas como verdaderos tecnicismos. Numerosas voces de origen metafórico se lexicalizaron, a través de un proceso de catacresis, y han pervivido hasta nuestros días, según demuestra su inclusión en el $D R A E$ como términos de

${ }^{60}$ En el Tesoro de la lengua castellana de Sebastián de Covarrubias (1611) se da cuenta del origen metafórico del término: «Cerca de los arquitectos son los pies derechos de las puertas o ventanas por ser como piernas que sustentan el lintel. Jambas y gambas todo es uno. El vocablo es francés, JAMBE, crus, tibia. El italiano la llama gamba» (s. v. jambas). También el Diccionario de Autoridades propone un origen metafórico para la voz: «Los pies u como piernas que en las puertas o ventanas mantienen el dintel. Viene de la voz italiana Gamba, que significa la pierna» (s. v. jambas).

${ }^{61} \mathrm{He}$ comprobado que Sagredo es la primera documentación con búsquedas en el DCECH y en el CORDE. 
especialidad con la marca Arq. (v. g. corona o miembro $)^{62}$. Otras son propias de la arquitectura renacentista, como vientre, que en los textos se emplea como sinónimo del éntasis grecolatino. El DRAE no recoge una acepción de vientre referida a la arquitectura, a pesar de que acoge la poco usada voz éntasis ${ }^{63}$ («Arq. parte más abultada del fuste de algunas columnas») y el sinónimo barriga, término patrimonial y de origen metafórico, con la definición: 'parte media abultada de una vasija, columna, etc.' . La voz vientre, a pesar de su especifidad, también ha pasado desapercibida por los diccionarios históricos de la construcción, pues no la incluyen Rejón de Silva (1788), Bails (1802), Matallana (1848) ni García Salinero (1968), y sólo Vera (2004) recoge la palabra atribuyéndola a León Battista Alberti. ${ }^{64}$ Merecería la pena que los estudios históricos tuvieran en cuenta éste y otros términos importantes que no han sido atendidos, como calva, corteza, costado, costra, hueso, meollo, ombligo, raíz, ren, tuétano o tronco. A pesar de que se trata de voces muy expresivas y de que, en ocasiones, como ocurre con hueso, pueden referirse a más de un elemento arquitectónico, lo que explica que se detuviera su proceso de lexicalización y que no se consolidaran como términos, ${ }^{65}$ merecen estudiarse como parte del léxico de la construcción, pues en los textos designan inequívocamente piezas de la edificación (p. e. costra, 'revestimiento de suelos, techos y paredes', o tronco, 'fuste') o bien partes de ésta, en función de la posición que ocupan (p. e. costado, ${ }^{66}$ 'parte lateral de un edificio'). ${ }^{67}$ En definitiva, las voces figuradas contribuyen al nacimiento del léxico moderno de la construcción y sin ellas no es posible comprender cabalmente la teoría arquitectónica renacentista.

${ }^{62}$ Corona: «22. Arq. Una de las partes de que se compone la cornisa, que está debajo del cimacio» (DRAE, $s$. v.); y miembro: «5. m. Arq. Cada una de las partes principales de un orden arquitectónico o de un edificio» (DRAE, s. v.). $C$. también el caso de nervio, ya comentado.

${ }^{63}$ De hecho, en el CORDE, éntasis sólo se documenta una vez en un texto moderno (Manuel Gómez-Moreno, Las águilas del Renacimiento español, 1941).

${ }^{64} \mathrm{La}$ voz vientre, en su acepción referida a la arquitectura, tampoco aparece en Terreros (1786-1793) ni en el Diccionario de Autoridades. A pesar de que Vera (2004) recoge las voces de Las medidas del romano, no ha advertido que Sagredo (1526) también empleó vientre en las pp. 33 y 46 de su tratado.

${ }^{65}$ En este sentido, Villar Díaz destaca el hecho de que, para que se dé un proceso de catacresis o lexicalización de una expresión metafórica, se precisa que haya concreción semántica: «Parece que, a mayor concreción semántica, mayor grado de lexicalización, mientras que, a mayor extensión, menor capacidad de integración en la lengua. Ello quiere decir que aquellos términos que dan lugar a una auténtica catacresis son aplicados a un número más o menos reducido y concreto de referentes, al contrario de lo que sucede con aquellos otros que permanecen en la línea de indeterminación que se halla entre la catacresis y la metáfora» (2001: 346-347).

${ }^{66} \mathrm{El}$ término costado puede equipararse a otras voces que designan posición, como ocurre con frente, definida en el Diccionario de Autoridades como 'fachada o lo primero que se ofrece a la vista de un edificio u otra cosa', y en Terreros (1786-1793) como sinónimo de 'fachada' y en el DRAE como 'fachada o parte primera que se ofrece a la vista en un edificio u otra cosa'.

${ }^{67}$ En este sentido, trabajos como Vera (2004) muestran su acierto al incluir algunos de estos términos. De la lista mencionada, Vera (2004) dedica sendas entradas lexicográficas a corteza, costra y hueso. 


\section{REFERENCIAS BIBLIOGRÁFICAS}

AlBERTI, Leon Battista (1966 [1485]): L'architettura (De re aedificatoria), testo latino e traduzione a cura di Giovanni Orlandi, introduzione e note di Paolo Portoghesi, Milano, Edizioni il Polifilo.

Arfe y Villafañe, Juan de (2005 [1585-1587]): De Varia Commensuración para la Esculptura y Architectura, Sevilla, Andrea Pescioni y Juan de León, edición en M. J. Mancho Duque, dir., y Mariano Quirós García, coord. (2005): La ciencia y la técnica en la época de Cervantes: textos e imágenes, Salamanca, Universidad de Salamanca, CD-Rom.

BAILs, Benito (1973 [1802]): Diccionario de arquitectura civil, Oviedo, Colegio de Aparejadores y Arquitectos Técnicos de Asturias, ed. facsímil.

Bartoli, Cosimo (1550): Leon Battista Alberti, L'Architettura di Leonbatista Alberti, trad. Cosimo Bartoli, Firenza, Lorenzo Torrentino.

Bustamante, Agustín, Fernando Marías, Ma Jesús Del Olmo y Natividad Sánchez Esteban (1986): «Catálogo», en El Escorial en la Biblioteca Nacional, Madrid, Ministerio de Cultura, pp. 149219.

Bustamante, Agustín y Fernando Marías (1986): «El Escorial y la cultura arquitectónica de su tiempo», El Escorial en la Biblioteca Nacional, Madrid, Ministerio de Cultura, pp. 117-148.

CAllebat, Louis (1995): «Dénominations métaphoriques dans le vocabulaire de l'arquitecture», en Louis Callebat, coord., Actes du $4^{e}$ colloque international sur le latin vulgaire et tardif (Caen, 25 septembre, 1994), Hildesheim-Zürich-New York, Olms-Weidmann, pp. 633-642.

— y Philipe Fleury (1995): Dictionnaire des termes techiques du «De architectura de Vitruve», Hildesheim, George Olms.

CÁmara Muñoz, Alicia (1990): Arquitectura y sociedad en el Siglo de Oro, Madrid, El Arquero.

Cantillo Nieves, Ma Teresa (2005): «El uso de la metáfora y la extensión metonímica en el léxico de la destilación quinientista», en M. ${ }^{a}$ Carmen Cazorla, Narciso M. Contreras, M. ${ }^{a}$ Ángeles García y M. ${ }^{a}$ Águeda Moreno, coords., Estudios de historia de la lengua e historiografia lingüistica. Actas del III Congreso Nacional de la Asociación de Jóvenes Investigadores de Historiografía e Historia de la Lengua Española, CERSA, Madrid, pp. 105-115.

CAXesi, Patricio (1593): Jacome de Vignola, Regla de las cinco órdenes de Architectura, trad. Patritio Caxesi, Madrid, en casa del autor.

Chamizo Domínguez, Pedro José (1998): Metáfora y conocimiento, Málaga, Universidad de Málaga, Anejo XVI de Analecta Malacitana.

Clairac y SÁenz, Pelayo (1877-1891): Diccionario general de arquitectura e ingeniería, Madrid, Zaragozano y Jayme, (a-puerto).

CovarRubias y Horozco, Sebastián de (1943 [1611]): Tesoro de la lengua castellana o española; ed. según la impresión de 1611, con las adiciones de Benito Remigio Noydens publicadas en la de 1674 [Madrid, Melchor Sánchez], de Martín de Riquer, Barcelona, Horta (reimpr. Barcelona, Altafulla, 1987).

CORDE. Real ACAdemia Española, Corpus Diacrónico del Español, en http: //www.rae.es, 2005.

Criado Mainar, Jesús (2004): «Técnica y estética: los tratados de arquitectura», en Manuel Silva, ed., Técnica e ingeniería en España. El Renacimiento, Zaragoza, Real Academia de IngenieríaInstitución Fernando el Católico-Prensas de la Universidad de Zaragoza, pp. 201-238. 
Cruz Valdovinos, José Manuel (1980): «Miguel de Urrea, entallador de Alcalá y traductor de Vitruvio», Anales del Instituto de Estudios Madrileños, XVII, pp. 67-72.

DCECH. Joan Corominas y José Antonio Pascual (1980-1991): Diccionario crítico etimológico castellano e hispánico, Madrid, Gredos.

Diccionario de Autoridades. ReAl ACADEMIa Española (1726-1739): Diccionario de la lengua castellana, Madrid, Imprenta de Francisco del Hierro-Herederos de Francisco del Hierro (reimpr. facsímil, Diccionario de Autoridades, Madrid, Gredos, 1990).

DRAE-1884. Real Academia Española (1884 ${ }^{12}$ ): Diccionario de la lengua castellana, Madrid, Gregorio Hernando.

DRAE-2001. Real ACAdemia Española (200122): Diccionario de la lengua española, Madrid, EspasaCalpe.

DeIgnan, Alice (2005): Metaphors and Corpus Linguistics, Amsterdam (Philadelphia), John Benjamins.

Elia, Paola y Ma Jesús MAncho (2002): San Juan de la Cruz, Cántico espiritual y poesía completa, ed. de Paola Elia y Ma Jesús Mancho, estudio preliminar de Domingo Ynduráin, Barcelona, Crítica.

Fullana, Miquel (1995'): Diccionari de l'art i dels oficis de la construcció, il·lustrat amb més de 700 dibuixos a ploma pel mateix autor, Mallorca, Moll.

García Melero, José Enrique (1986): «Las ediciones españolas de De Architectura de Vitruvio», Fragmentos, 8-9, pp. 102-131.

García Morales, Ma Victoria (1991): La figura del arquitecto en el siglo XVII, Madrid, UNED.

García Salinero, Fernando (1968): Léxico de alarifes de los Siglos de Oro, Madrid, Real Academia Española.

Grafton, Anthony (2000): Leon Battista Alberti. Master builder of the Italian Renaissance, New York, Hill and Wang.

Gutiérrez Rodilla, Bertha M. (1998): La ciencia empieza en la palabra. Análisis e historia del lenguaje científico, Barcelona, Península.

Herráez Cubino, Guillermo (2006): «Terminología de canteros renacentistas españoles: las voces que entre canteros llamamos, según Alonso de Vandelvira», en Javier Rodríguez Molina y Daniel Sáez Rivera, coords., Actas del IV Congreso Nacional de la Asociación de Jóvenes Investigadores de Historiografía e Historia de la Lengua española (Madrid, 1, 2 y 3 de abril de 2004), Madrid, Síntesis, 2006, pp. 343-354.

Herráez Cubino, Guillermo (2007a): «Lexicografía menor en los tratados de arquitectura y construcción en el siglo XVI: El Vocabulario de los nombres obscuros y difficultosos que en Vitruvio se contienen de Miguel de Urrea (1582)», en Mar Campos, Rosalía Cotelo y José Ignacio Pérez Pascual, eds., Historia de la lexicografía española, A Coruña, Universidad de A Coruña, Anexos Revista de Lexicografía, 7, pp. 95-102.

Herráez Cubino, Guillermo (2007b): El léxico de los tratados de cortes de cantería españoles del siglo $X V I$, tesis doctoral dir. por M. . Jesús Mancho Duque, Salamanca, Universidad de Salamanca, CD-Rom.

Johnson, Mark (1984): The Body in the Mind. The Bodily Basis of Meaning, Imagination, and Reason, Chicago-Londres, University of Chicago Press.

LaKofF, George y Mark Johnson (1980): Metaphors We Live By, Chicago, University of Chicago. 
Llamas saíz, Carmen (2005): Metáfora y creación léxica, Pamplona, EUNSA.

LE GUERn, Michel (1973): Sémantique de la métaphore et de la métonymie, Paris, Larousse.

Lozano, Francisco (1582): Los diez libros de Architectura de León Baptista Alberto, Madrid, Alonso Gómez, ed. en Ma José Mancho Duque, dir., y Mariano Quirós García, coord. (2005): La ciencia y la técnica en la época de Cervantes: textos e imágenes, Salamanca, Universidad de Salamanca, CD-Rom.

Mancho Duque, Ma Jesús (2001): «La lengua española, vehículo de divulgación científica en el Renacimiento», en $\mathrm{M}^{\mathrm{a}}$ Jesús Mancho Duque, dir., y Cristina Blas Nistal, coord., Pórtico a la ciencia y la técnica del Renacimiento, Salamanca, Junta de Castilla y León-Consejería de Educación y Cultura-Universidad de Salamanca, pp. 45-84.

Mancho Duque, Ma Jesús (2003): «Aproximación al léxico de la ciencia aplicada en el Renacimiento hispano», Asclepio, LV, 2, pp. 27-42.

MANCho DuQue, Ma Jesús (2004): «La divulgación técnica: características lingüísticas», en Manuel Silva, ed., Técnica e ingeniería en España. El Renacimiento, Zaragoza, Real Academia de Ingeniería-Institución Fernando el Católico-Universidad de Zaragoza, pp. 307-340.

Mancho Duque, Ma Jesús (2005): «La metáfora corporal en el lenguaje científico-técnico del Renacimiento», en Ma José Albalá et al., eds., Filología y lingüística. Estudios ofrecidos a Antonio Quilis, Madrid, CSIC-UNED-Universidad de Valladolid, I, pp. 791-805.

Mancho Duque, Ma Jesús, dir., y Mariano Quirós GarcíA, coord. (2005): La ciencia y la técnica en la época de Cervantes: textos e imágenes, Salamanca, Universidad de Salamanca, CD-Rom.

MaQuieIRA, Helena (1998): «La metáfora en el léxico médico de origen griego», Tarbiya, 18, pp. 53-61.

Matallana, Mariano (1848): Vocabulario de arquitectura civil, Madrid, Francisco Rodríguez.

MARÍAs, Fernando (2000): «Diego de Sagredo, entre arquitectura y escritura», estudio introductorio a Fernando Marías y Felipe Pereda, eds., Diego de Sagredo, Medidas del romano, Madrid, Colegio Oficial de Arquitectos de Castilla-La Mancha, pp. 11-50.

MaríAs, Fernando y Agustín Bustamante (1986): «Prólogo» a Diego de Sagredo, Medidas del romano, Madrid, Dirección General de Bellas Artes y Archivos-Consejo General de Colegios Oficiales de Aparejadores y Arquitectos Técnicos, pp. 5-139.

Martín Municio, Ángel (1992): «La metáfora en el lenguaje científico», Boletín de la Real Academia Española, CCLVI, pp. 221-249.

Morales, Alfredo J. (1994): «Arte y ciencia en la Sevilla del siglo XVI. Los manuscritos del cosmógrafo Rodrigo Zamorano», en Actas del X Congreso del Comité Español de Historia del Arte (Madrid, 27-30 de septiembre de 1994), Madrid, UNED, pp. 453-457.

Morales, Alfredo J. (1995): «El cosmógrafo Rodrigo Zamorano, traductor de Alberti al español», Annali d'archittetura, 7, pp. 141-146.

Paniagua, José Ramón (19989): Vocabulario básico de arquitectura, Madrid, Cátedra.

PASCUAL, José Antonio (1987): "De problemas, necesidades y perspectivas en el estudio de la terminología de la edificación”, en I Congreso Hispanoamericano de Terminología de la Edificación, Valladolid, Comité Hispanoamericano de la Edificación, pp. 8-14. 
Pizarro Gómez, Francisco Javier y Pilar Mogollón Cano-Cortés (1999): «Estudio del manuscrito y de su autor», en Lázaro de Velasco, Los X libros de arquitectura de Marco Vitruvio Polión, Cáceres, Cicón Ediciones, pp. 15-74.

REJÓn DE SILVA, Diego Antonio (1788): Diccionario de las nobles artes para instrucción de los aficionados y uso de los profesores, Segovia, Antonio Espinosa.

Rico, Francisco (1986): El pequeño mundo del hombre: Varia fortuna de una idea en la cultura española, Madrid, Alianza.

SAgredo, Diego de (1526): Medidas del Romano, Toledo, Remon de Petras, 1526, ed. en Ma Jesús Mancho Duque, dir., y Mariano Quirós García, coord. (2005): La ciencia y la técnica en la época de Cervantes: textos e imágenes, Salamanca, Universidad de Salamanca, CD-Rom.

SÁnchez MARTín, Francisco Javier (2005): La medición en la ciencia y la técnica del Renacimiento. Estudio léxico, trabajo de grado inédito, dir. Ma Jesús Mancho Duque, Salamanca, Universidad de Salamanca.

SAntos Domínguez, Luis Antonio y Rosa María espinosa Elorza (1996): Manual de semántica histórica, Madrid, Síntesis.

Terreros y Pando, Esteban (1786-1793): Diccionario castellano con las voces de ciencias y artes, Madrid, Ibarra.

Urrea, Miguel de (1582): M. Vitruvio Pollión De Architectura, Alcalá de Henares, Juan Gracián.

Velasco, Lázaro de (1999 [1555]): Los X libros de arquitectura de Marco Vitruvio Polión, estudio y transcripción de Francisco Javier Pizarro Gómez y Pilar Mogollón Cano-Cortés, Cáceres, Cicón Ediciones.

VERA Boti, Alfredo (2004): Arquitectura del Renacimiento. Elucidario. Significado de los términos según los trataditas y evolución histórica de los elementos utilizados en la arquitectura, sus oficios y el urbanismo, Murcia, Academia Alfonso X el Sabio.

VILlar DíAz, Ma Belén (2001): «Catacresis y extensión metafórica», en José Antonio Bartol Hernández, coord., Nuevas aportaciones al estudio de la lengua española: investigaciones filológicas, Salamanca, Luso-Española de Ediciones, pp. 341-351. 